\title{
Internet use by orthopedic and traumatology patients in Turkey
}

\section{Türkiye'de ortopedi ve travmatoloji hastaları tarafından internet kullanımı}

\author{
*Özhan Pazarcı ${ }^{1}$, Umut Hatay Gölge ${ }^{2}$, Yalkın Çamurcu ${ }^{3}$, Hakan Saygılı ${ }^{4}$, Seyran \\ Kılınç ${ }^{5}$, Mehmet Vakıf Keskinbıçkı ${ }^{6}$, Murat Korkmaz ${ }^{7}$ \\ ${ }^{1}$ Orthopaedics and Traumatology Clinic, Reyhanlı State Hospital, Hatay, Turkey
${ }^{2}$ Department of Orthopaedics and Traumatology, Çanakkale Onsekiz Mart Üniversity School of Medicine, Çanakkale,
Turkey
${ }^{3}$ Orthopaedics and Traumatology Clinic, Devrek State Hospital, Zonguldak, Turkey
${ }^{4}$ Orthopaedics and Traumatology Clinic, Kozan State Hospital, Adana, Turkey
${ }^{5}$ Department of Orthopaedics and Traumatology, Cumhuriyet Üniversity School of Medicine, Sivas, Turkey
${ }^{6}$ Orthopaedics and Traumatology Clinic, Şırnak State Hospital, Şırnak, Turkey
${ }^{7}$ Department of Orthopaedics and Traumatology, Bozok Üniversity School of Medicine, Yozgat, Turkey
Corresponding author: Dr. Orhan Pazarcı, Ortopedi ve Travmatoloji Kliniği, Reyhanlı Devlet Hastanesi, TR 31500
Hatay, Türkiye
E-mail: dr.pazarci@gmail.com
Received/Accepted: June 16, 2015/October 22, 2015
Conflict of interest: There is not a conflict of interest.
}

\section{SUMMARY}

Objective: Internet and social media are used at a significant rate in the decision process related to health of patients. In our study we aimed to investigate the socio-demographic characteristics, and internet use, attitude and behavior oforthopedics and traumatology patients according to diagnosis. Method: Patients filled in a face-to-face survey form during clinical examination. The surveys were completed in the following provinces, from east to west, Şırnak, Sivas, Yozgat, Hatay, Adana and Çanakkale.According to diagnosis patients were divided into subgroups of arthroplasty, arthroscopic knee surgery, ankle surgery, shoulder and elbow surgery, spinal surgery, trauma, pediatric orthopedic, hand surgery and microsurgery, and soft tissue and bone tumor patients. Additionally patients were asked whether they had internet at home and whether they were social media users. The patients were asked if they had researched their disease or doctor on the internet. Results: 600 patients who participated in the study 287 were male (47.8\%) and 313 were female $(52.2 \%)$. The mean age of patients was $40.4 \pm 21.6$ years $(0-91$ years) with the mean age of males $37.9 \pm 21.1(0-85)$ years and mean age of females $42.6 \pm 21.9(0-91)$ years.Evaluating the relationship between internet use; disease group (arthroplasty, arthroscopy, spine, pediatric orthopedic, etc.), type of hospital (university, provincial state, county state), place of residence, educational level, age and gender are examined, there were a statistically difference all of groups. Of the 600 patients participating in the research $304(50.7 \%)$ had a home internet connection and 234 people $(39 \%)$ said they actively used social media. Of the 600 patients, $107(17.8 \%)$ reported they researched their disease with the help of the internet and only 56 patients $(9.3 \%)$ reported researching their doctor with the help of the internet.

Conclucion: Popularity of internet use has increased the internet use to obtain information about healthcare. Knowing the frequency of internet use by patients will aid in developing resources to inform patients. In the future developing social media and the internet will continue to be integrated into health services and orthopedics to guide patient decisions. It appears that the most important source of information about health remains health personnel.

Keywords: Internet, socialmedia, orthopaedicsurgery

ÖZET

Amaç: İnternet ve sosyal medya sağlıkla ilgili karar sürecinde hastalar tarafindan önemli oranda kullanılmaktadır. Çalışmamızda Türkiye'de ortopedi ve travmatoloji kliniğine başvuran bireylerin 
sosyo-demografik özellikleri ve tanılarına göre internet kullanım tutum ve davranışlarını incelemeyi amaçladık.

Yöntem: Hastalar poliklinik muayeneleri sırasında yüz yüze anket formları dolduruldu. Anketler doğudan batıya Şırnak, Sivas, Yozgat, Hatay, Adana ve Çanakkale illerinde yapıldı. Tanılarına göre hastalar; artroplasti, artroskopi diz cerrahisi, ayak ayakbileği cerrahisi, omuz ve dirsek cerrahisi, omurga cerrahisi, travma, pediatrik ortopedi, el cerrahisi ve mikrocerrahi, yumuşak doku ve kemik tümörü hastaları olarak alt gruplara ayrılarak incelendi. Ayrıca hastaların evlerinde internet olup olmaması, sosyal medya kullanıcısı olup olmadıkları soruldu. Hastaların hastalıkları hakkında ya da doktoru hakkında internetten araştırma yapıp yapmadığı soruldu.

Bulgular: Çalışmaya katılan 600 hastanın 287'si erkek (\%47,8), 313'ü kadındı (\%52,2). Hastaların yaş ortalaması 40,4 \pm 21,6 olup (0-91 yaş arası); erkeklerin yaş ortalaması 37,9 $\pm 21,1$ (0-85 yaş arası), kadınların yaş ortalaması ise 42,6 \pm 21,9 (0-91 yaş arası) idi. İnternet kullanımı ile; hastalık grubu (artroplasti, artroskopi, vertebra, pediatrik ortopedi, vb), hastane tipi (üniversite, il ve ilçe devlet hastanesi), ikamet edilen yer, eğitim seviyesi, yaş ve cinsiyet arasındaki ilişki incelendi ve tüm gruplar arasında istatistiksel olarak anlamlı fark görüldü. Araştırmaya katılan 600 hastadan 304'ünün $(\% 50,7)$ evinde internet bağlantısı bulunuyordu ve 234 kişi sosyal medyay1 aktif olarak kullandığını bildirdi (\%39); 600 hastadan 107'si (\%17,8) hastalığını internet yardımıyla araştırdığını bildirdi ve sadece 56 hasta $(\% 9,3)$ doktorunu internet yardımıyla araştırdı̆̆ını bildirdi.

Sonuç: İnternet kullanımının yaygınlaşması ile birlikte sağlık alanında bilgi edinme amaçlı internet kullanımıda artmıştır. Hastaların internet kullanım sıklığının bilinmesi, hastaların bilgilendirilmesi için kullanılacak kaynakların geliştirilmesine yardımcı olur. Gelecekte gelişen sosyal medya ve internet hastaların kararlarına rehberlik etmede sağlık hizmetleri ve ortopediye entegre olmaya devam edecektir. Sağlık hakkında bilgi edinmenin en önemli kaynağı halen sağlık çalışanları olarak görülmektedir.

Anahtar sözcükler: İnternet, sosyal medya, ortopedi ve travmatoloji

\section{INTRODUCTION}

Developing internet technology has caused changes in medical practice ${ }^{1}$. The internet developed in the 1990s and forms an indispensable part of daily life ${ }^{2}$. It is clear that the internet, one of the greatest developments in the field of communication, will cause great changes in working conditions in healthcare in the future ${ }^{2}$. In addition to the rapid development of the internet changing the diagnosis and treatment of patients, it has changed the perception, attitude and behavior of patients ${ }^{3}$. Globally when daily search topics on the internet are examined, $4.5 \%$ are related to health ${ }^{4}$. Knowing the frequency of internet use by patients will help develop resources to inform patients and allow clinicians to control the content of information reached by patients ${ }^{2}$. Internet and social media are used at a significant rate in the decision process related to health of patients 3 . In our study we aimed to investigate the socio-demographic characteristics, and internet use, attitude and behavior of orthopedics and traumatology patients according to diagnosis.

\section{MATERIAL AND METHODS}

Patients filled in a face-to-face survey form during clinical examination. The surveys were completed in the following provinces, from east to west, Şırnak, Sivas, Yozgat, Hatay, Adana and Çanakkale. The hospitals where the survey was carried out were grouped as county state, provincial state and university hospital. The age, gender, educational level and place of residence (village, county, city) of patients were recorded. It was noted whether the patient was an orthopedic or traumatology patient. According to diagnosis patients were divided into subgroups of arthroplasty, arthroscopic knee surgery, ankle surgery, shoulder and elbow surgery, spinal surgery, trauma, pediatric orthopedic, hand surgery and microsurgery, and soft tissue and bone tumor patients. Additionally patients were asked whether they had internet at home and whether they were social media users. The patients were asked if they had researched their disease or doctor on the internet. Local ethics committee permission was obtained. For statistical analysis, data were analyzed using the SPSS 20.0 (IBM, NY, USA) program. To compare qualitative variables in independent groups, the non-parametric Pearson ChiSquare test was used. A $p$ value of less than 0.05 was accepted as statistically sig- 
nificant $(\mathrm{p}<0.05)$.

\section{RESULTS}

Of 600 patients who participated in the study 287 were male $(47.8 \%)$ and 313 were female $(52.2 \%)$. The mean age of patients was $40.4 \pm 21.6$ years $(0-91$ years $)$ with the mean age of males $37.9 \pm 21.1(0$ 85 ) years and mean age of females $42.6 \pm$ 21.9 (0-91) years. When educational level is examined, 125 people $(20.8 \%)$ were illiterate, $193(32.2 \%)$ were primary school graduates, $73(12.2 \%)$ were middle school graduates, $126(21 \%)$ were high school graduates and 83 people (13.8\%) were university graduates. Of patients participating in the survey $132(22 \%)$ lived in villages, $262(43.7 \%)$ lived in counties and $206(34.3 \%)$ lived in city centers.

In terms of the research regions, there were $102(17 \%)$ patients in the 1 st region $(\mathrm{Si}-$ vas), $101(16.8 \%)$ patients in the 2 nd region (Hatay), $101(16.8 \%)$ in the 3rd region (Yozgat), $106(17.7 \%)$ patients in the 4th region (Adana), 87 (14.5\%) patients in the 5th region (Çanakkale) and 103 $(17.2 \%)$ in the 6th region (Şırnak). When the research hospitals are examined, 290 $(48.3 \%)$ patients attended university hospitals, $103(17.2 \%)$ attended provincial state hospitals and 207 (34.5\%) patients attended county state hospitals.

Of patients participating in the research $388(64.7 \%)$ were orthopedic patients while $212(35.3 \%)$ were trauma patients. When patients are grouped according to disease, 60 patients were in the arthroplasty group, 113 patients were in the arthroscopy and knee surgery group, 80 patients were in the foot and ankle surgery group, 49 patients were in the shoulder and elbow surgery group, 52 patients were in the spinal surgery group, 144 patients were in the trauma group, 24 patients were in the pediatric orthopedic group, 60 patients were in the hand surgery group and 18 patients were in the tumor surgery group.

Of the 600 patients participating in the research $304(50.7 \%)$ had a home internet connection and 234 people (39\%) said they actively used social media. Of the 600 patients, $107(17.8 \%)$ reported they researched their disease with the help of the internet and only 56 patients (9.3\%) reported researching their doctor with the help of the internet.

When the relationship of internet use of patients with gender is evaluated, the use of the internet by male patients was higher by a statistically significant degree compared to female patients $(\mathrm{p}=0.004$; $\mathrm{p}=0.000 ; \mathrm{p}=0.012 ; \mathrm{p}<0.05)$. When the relationship of internet use with age and educational level is examined, there was a statistically significant difference found between age and educational groups $(\mathrm{p}=0.000 ; \mathrm{p}<0.05)($ Tables 1,2$)$.

When the relationship of internet use with place of residence and region is evaluated, internet use, social media use, internet research of disease and doctor varied by a statistically significant degree depending on place of residence $(\mathrm{p}=0.000 ; \mathrm{p}<0.05)$ (Table 3).

Evaluating the relationship between internet use and type of hospital (university, provincial state, county state) showed that internet use, social media use, internet research of disease and doctor varied by a statistically significant degree depending on type of hospital attended $(\mathrm{p}=0.000$; $\mathrm{p}<0.05)$.

Evaluating the relationship between internet use and disease group (arthroplasty, arthroscopy, spine, pediatric orthopedic, etc.), the internet use, social media use, internet research of disease and doctor varied by a statistically significant degree depending on disease group $(\mathrm{p}=0.000$; $\mathrm{p}<0.05)$ (Table 4).

\section{DISCUSSION}

As a result of individuals reaching information on the internet, they have become more informed about their diseases. This has pushed doctors to become more informed about the internet1. Knowing the frequency of internet use among patients will help develop resources used to inform patients and allow clinicians to control the content of information reached by patients $^{2}$. Our study aimed to investigate the socio-demographic characteristics, and internet use, attitude and behavior of patients according to diagnosis. 
In addition to the rapid development of the internet changing the diagnosis and treatment of patients, it has changed the perception, attitude and behavior of patients ${ }^{3}$. Globally when daily search topics on the internet are examined, $4.5 \%$ are related to health4. According to 2013 data internet use in the USA was $85 \%$ and among these users $72 \%$ of searches were for health information ${ }^{5}$. Internet use in Turkey is $48.9 \%$. In our research incorporating different regions in Turkey, of 600 patients $304(50.7 \%)$ had home internet connection, while 234 (39\%) were active social media users. In our study while 107 of the 600 patients $(17.8 \%)$ had researched their disease with the aid of the internet, only 56 patients $(9.3 \%)$ appeared to have used the internet to choose their doctor. The rate of searches for topics related to health among internet users in Turkey is $59.6 \%{ }^{6}$. This rate leads to the conclusion that, similar to other countries, in Turkey the internet may be used to share information about health topics, to inform healthy individuals as well as patients, and for education ${ }^{1}$. We believe that this rate will increase even further in Turkey within a short time.

Similar to the distribution of internet use according to gender in our study, in Turkey the rate is higher for males ${ }^{6}$. As age increases, internet use decreases ${ }^{6}$ (Table 1). In our country due to increases in educational level and access to the internet, we believe this will change in the future.

Table 1: Age and internet use.

\begin{tabular}{l|lllll}
\hline Age & Number & Internet use $(\boldsymbol{\%})$ & $\begin{array}{l}\text { Social media use } \\
(\boldsymbol{\%})\end{array}$ & $\begin{array}{l}\text { Internet research of } \\
\text { disease }(\boldsymbol{\%})\end{array}$ & $\begin{array}{l}\text { Internet research of } \\
\text { doctor }(\boldsymbol{\%})\end{array}$ \\
\hline $0-18$ & 128 & $57.8 \%$ & $46.0 \%$ & $12.5 \%$ & $5.4 \%$ \\
$19-29$ & 88 & $72.7 \%$ & $61.4 \%$ & $37.5 \%$ & $20.4 \%$ \\
$30-39$ & 80 & $58.7 \%$ & $50.0 \%$ & $30.0 \%$ & $16.2 \%$ \\
$40-49$ & 90 & $41.1 \%$ & $35.3 \%$ & $13.3 \%$ & $4.4 \%$ \\
$50-59$ & 71 & $35.2 \%$ & $22.5 \%$ & $8.4 \%$ & $8.4 \%$ \\
$60-69$ & 80 & $42.5 \%$ & $25.0 \%$ & $13.7 \%$ & $5.0 \%$ \\
$>70$ & 63 & $36.5 \%$ & $20.6 \%$ & $7.9 \%$ & $6.3 \%$ \\
\hline Toplam & $\mathbf{6 0 0}$ & $\mathbf{\% 5 0 . 6}$ & $\mathbf{3 9 \%}$ & $\mathbf{1 7 . 8 \%}$ & $\mathbf{9 . 3 \%}$ \\
\hline
\end{tabular}

In our study it was observed that the higher the educational level among orthopedic and traumatology patients, the higher the rate of internet use (Table 2). Data from the Turkish Statistical Institute provides similar results to our study ${ }^{6}$. Patients can take greater initiative in informing themselves about their health by using the internet $^{7}$. Individuals can easily access correct-incorrect, insufficient-too much information about their disease using the internet $^{3}$. If patients reach correct information on the internet, it may lead to more successful disease management ${ }^{8}$. As educational level and internet use increases, we think patients will take greater initiative about their health. Similar studies in the literature have emphasized the relationship between educational level and internet use. In 2008 a study including a total of 1400 patients, 700 general surgery and 700 relatives, it was found that the rate of internet use in daily life was $29.8 \%$.

According to educational level, the rate was $27.5 \%$ for high school or above graduates, with $2.3 \%$ use by those with middle school and lower educational levels. It was observed that $16.7 \%$ of patients had researched their disease on the internet ${ }^{2}$. 
Table 2: Educational level and internet use.

\begin{tabular}{llllll}
\hline Education & Number & Internet use (\%) & $\begin{array}{l}\text { Social media use } \\
(\mathbf{\% )}\end{array}$ & $\begin{array}{l}\text { Internet research } \\
\text { of disease (\%) }\end{array}$ & $\begin{array}{l}\text { Internet research } \\
\text { of doctor (\%) }\end{array}$ \\
\hline İlliterate & 125 & $19.2 \%$ & $4.8 \%$ & $0.8 \%$ & $1.6 \%$ \\
Primary school & 193 & $31.1 \%$ & $14.5 \%$ & $6.2 \%$ & $5.2 \%$ \\
Middle school & 73 & $58.9 \%$ & $46.6 \%$ & $13.7 \%$ & $5.5 \%$ \\
High school & 126 & $81.7 \%$ & $75.4 \%$ & $20.6 \%$ & $11.1 \%$ \\
University & 83 & $89.2 \%$ & $85.5 \%$ & $69.9 \%$ & $31.3 \%$ \\
\hline
\end{tabular}

Table 3: The relationship of internet use with place of residence and region.

\begin{tabular}{llllll}
\hline Residence & Number & Internet use (\%) & Social media use (\%) & $\begin{array}{l}\text { Internet research } \\
\text { of disease }(\%)\end{array}$ & $\begin{array}{l}\text { Internet research } \\
\text { of disease (\%) }\end{array}$ \\
\hline Village & 132 & $14.4 \%$ & $7.6 \%$ & $1.5 \%$ & $3.0 \%$ \\
Town & 262 & $46.6 \%$ & $34.4 \%$ & $10.3 \%$ & $3.8 \%$ \\
\hline
\end{tabular}

Table 4: Disease group and internet use.

\begin{tabular}{llllll}
\hline Disease group & Number & Internet use $(\boldsymbol{\%})$ & $\begin{array}{l}\text { Social media use } \\
(\boldsymbol{\%})\end{array}$ & $\begin{array}{l}\text { Internet research } \\
\text { of disease }(\boldsymbol{\%})\end{array}$ & $\begin{array}{l}\text { Internet research } \\
\text { of disease }(\%)\end{array}$ \\
\hline Arthroplasty & 60 & $20.0 \%$ & $15.0 \%$ & $10.0 \%$ & $1.7 \%$ \\
Arthroscopy & 113 & $51.3 \%$ & $39.8 \%$ & $22.1 \%$ & $9.7 \%$ \\
Foot surgery & 80 & $56.3 \%$ & $48.8 \%$ & $21.3 \%$ & $11.3 \%$ \\
Shoulder elbow & 49 & $57.1 \%$ & $42.9 \%$ & $18.4 \%$ & $12.2 \%$ \\
Spine & 52 & $46.2 \%$ & $34.6 \%$ & $26.9 \%$ & $15.4 \%$ \\
Trauma & 144 & $52.8 \%$ & $42.4 \%$ & $7.6 \%$ & $4.9 \%$ \\
Pediatric & 24 & $54.2 \%$ & $45.8 \%$ & $33.3 \%$ & $6.2 \%$ \\
Hand surgery & 60 & $58.3 \%$ & $38.3 \%$ & $13.3 \%$ & $50.0 \%$ \\
Tumor & 18 & $72.2 \%$ & $38.9 \%$ & $50.0 \%$ & \\
\hline
\end{tabular}

Accessing information on the internet has advantages due to not being limited by the venue or time and allowing patients to reach similar patients ${ }^{9}$. The place of residence of patients affects internet use. Patients living in city centers are observed to use the internet more (Table 3). Sixty-three percent of patients emphasized that information obtained from the internet had reduced unnecessary doctor visits ${ }^{10}$.

The internet has allowed rapid and equal access to information that was once difficult to reach ${ }^{1}$.

When evaluated according to region, though statistically significant differences were identified, these changes were observed to be independent of the socioeconomic level of the province. In our study as educational level increased and population moved from rural to urban, the internet use was observed to increase. In England in research involving 3209 individuals obtaining health information from the internet, the incidence of searches for information related to health on the internet was determined to have a statistically significant correlation with socioeconomic level. Accordingly individuals in upper socio-economic groups were determined to search more for health information compared to individuals in lower socio-economic groups ${ }^{1}$.

In situations where information obtained from the internet is discussed with health consultants, it may be used to make the decision process related to health more efficient ${ }^{12}$. A sub-analysis of health information obtained from the internet found that $56 \%$ of those obtaining health information on the internet stated that obtaining health information through this channel provided awareness of how to check and manage their own health or that of someone else. Forty-nine percent stated that health information obtained from the internet changed their opinions of topics such as dieting, stress management and exercising $^{13}$. It has been observed that information obtained on the internet by patients is more effective when making decisions about the disease $^{12}$.

Accessing information on the internet has advantages such as not requiring a special, or indeed any, venue, no time limits, allowing 24 hour access, access to websites without identifying the house or patient, 
and possibility of accessing other, or peer, patients with the same disease ${ }^{9}$. Patients with orthopedic or trauma diagnosis accessing information on healthcare on the internet were not found to have any statistically significant difference in terms of researching disease or doctor through the internet or social media.

It was observed that among orthopedic sub groups the tumor subgroup researched disease and doctors most through the internet (Table 4). This was followed by pediatrics, spine, arthroscopy and foot surgery. The lowest rates of internet research were in the trauma and arthroplasty groups. In a study examining the aim of cancer patients obtaining information with internet use, 92 of 256 patients $(35 \%)$ stated they tried to obtain information by themselves or through others ${ }^{14}$. Additionally in a patient group with sports injuries, including young patients, it was found that internet use was greater among these patients ${ }^{21}$.

Patients do not separate information boundaries on the internet and may obtain incorrect information ${ }^{15}{ }^{16}$. A study of internet use by cancer patients found that access to information without checks on the correctness of the information led to early cessation of treatment, application of different treatments and damage to life ${ }^{17}$. The ability to obtain information related to health from a variety of websites creates contradictions in terms of reliability. Latthe et al. ${ }^{18}$ reported that information obtained on the internet may not always be reliable. It is not possible to audit all websites and websites prepared by clinicians and health organizations, including information on the diagnostic and treatment stages for patients, should be easily accessible, and present open and understandable information. At the same time the information obtained may increase treatment compliance by providing patients with an active role in treatment decision stages. Patients obtaining information about their diseases, treatment choices and possible treatment complications allows them to be more aware, and cope with anxiety stemming from ignorance ${ }^{2}$.

Our study has some limitations as it was not completed at more centers with greater numbers of patients.

Popularity of internet use has increased the internet use to obtain information about healthcare ${ }^{2}$. Knowing the frequency of internet use by patients will aid in developing resources to inform patients2. In the future developing social media and the internet will continue to be integrated into health services and orthopedics to guide patient decisions ${ }^{7}$. It appears that the most important source of information about health remains health personnel ${ }^{19,20}$.

\section{REFERENCES}

1. Doyle DJ, Ruskin KJ, Engel TP. The Internet and medicine; Past, present and future. Yale $\mathrm{J}$ Biol Med 1996; 69: 429-37.

2. Ozan Ş. Genel cerrahi hastalarının ve yakınlarının bilgi arayışında internet kullanımı. Turkısh journal of surgery $2008 ; 24: 156-9$.

3. Haluk Z. Hastaların İnternet Kullanımı ve Elektronik Ortamdaki Sağlık Bilgilerine Erişim Davranışları. F.N. Hem. Derg 2014; 22: 2147-4923.

4. Bass, S. B. Relatioship of internet health information use with patient behavior and self-efficacy: Experiences of newly diagnosed cancer patients who contact the national cancer institute's cancer information service. Journal of Health Communication 2006; 11: 219-36.

5. Internet World Stats (IWS). Internet Usage \& Population Statistics 2012,http://www.internetworldstat s.com/stats.html (31.12.2013).

6. Türkiye İstatsitik Kurumu (TÜIK). Hanehalkı Bilişim Teknolojileri Kullanım Araştırması 2013.

7. Jenine S. Effect of Social Media in Health Care and Orthopedic Surgery. 2012; 35: 4.

8. Barlow, JH, Stapley J, Ellard DR, Gilchrist M. Information and selfmanagement needs of people living with bleeding disorders: A survey. Hemophilia 2007; 13: 26470.

9. Nicholas D, Huntington P, Gunter B, Russell C, Withey R. The British and their use of the web for 
health information and advice: A survey. Aslib Proc 2003; 55: 26176.

10. Wanless D. Securing our future health: Taking a Long Term ViewFinal Report. HMGO The Public Unquiry Unit, London 2002.

11. Murray E. The impact of health information on the internet on health care and the physician-patient relationship: National US Survey. Journal of Medical Internet Research 2003; 5: 1727-34.

12. Broom A. Virtually he@lthy: The impact of internet use on disease experience and the doctor-patient relationship. Qualitative Health Research 2005; 15: 325-45.

13. Pew Internet\&American Life Project (PIALP). Health Information on the Internet US 2009.

14. Eda Y. Kanser hastalarının bilgi arayışında internet kullanımı. İnönü Üniversitesi Tip Fakültesi Dergisi 2005; 12: 125-8.

15. Hawn C. Take two aspirin and tweet me in the morning: how Twitter, Facebook, and other social media are reshaping healthcare. Health Aff 2009; 28: 361-8.

16. Department of Health and Human Services.

http://www.hhs.gov/ocr/privacy. Accessed 2011.

17. Kiley, R. Does the internet harm health? British Medical Journal 2002; 26: 235-41.

18. Latthe M, Latthe PM, Charlton R. Quality of information on emergency contraception on the internet. Br J Fam Plan 2000; 26: 3943.

19. Norum J, Grev A, Moen MA, Balteskard L, Holthe K. Information and communication technology (ICT) in oncology. Patients' and relatives' experiences and suggestions. Support Care Cancer 2003; 11: 286-93.

20. Ahmad F, Hudak PL, Bercovitz K, Hollenberg E, Levinson. W. Are physicians ready for patients with Internet-based health information? J Med Internet Res 2006; 8: 22.
21. Emily C. Prevalence of Internet and social media usage in orthopedic surgery. Orthopedic reviews 2014; 6: 5483. 